\title{
Characterization and Biological Activity of a Brazilian Isolate of Bacillus sphaericus (Neide) Highly Toxic to Mosquito Larvae
}

\author{
Paulo de Tarso Ribeiro Vilarinhos/ ${ }^{+}$, James E Maruniak*, Donald W Hall*
}

Instituto de Saúde do Distrito Federal, SGAN, Quadra 601, 70830-010 Brasília, DF, Brasil *Entomology and Nematology Department, University of Florida, Gainesville, Florida, USA

Primary powders of Bacillus sphaericus strain $S 2$ isolated from soil samples in Brazil, and strain 2362 were produced in a 14 liter fermentor. Growth patterns and sporulation observed in three trials with strains $S 2$ and 2362 in the fermentor were similar. Second-instar larvae of Culex quinquefasciatus, Anopheles albimanus, Anopheles quadrimaculatus, and Aedes aegypti exposed for $48 \mathrm{hr}$ to strain $\mathrm{S} 2$ responded with $L C_{50}$ values of $0.25,5.95,12.28$ and $140.0 \mathrm{ppb}$ of lyophilized primary powder, respectively. Under the same conditions, strain 2362 resulted in $L C_{50}$ values of 0.39, 7.16, 16.93 and 307.0 ppb of lyophilized primary powder, respectively, in those mosquito larvae. Statistical analysis of the bioassay data did not show significant differences among $L C_{50}$ values observed in $\mathrm{B}$. sphaericus strains S2 and 2362, at the 0.05 level.

Toxins of strains $S 2$ and 2362 were extracted at $\mathrm{pH} 12$ with $\mathrm{NaOH}$. Electrophoresis of the extracts in polyacrylamide gel under denaturing conditions revealed the 51 and $42 \mathrm{kDa}$ toxins in both $S 2$ and $2362 \mathrm{~B}$. sphaericus strains. The presence of the $42 \mathrm{kDa}$ peptide in the extracts was confirmed by Western blot and Elisa, with anti-42 kDa IgG previously prepared from strain 2362.

Key words: Bacillus sphaericus - mosquitoes - biological control - larvicide

Bacillus sphaericus has become an alternative agent for microbial control of mosquitoes since the isolation of highly larvicidal strains of this bacteria. Strain 2362, isolated from Simulium in Nigeria (Weiser 1984), is not toxic to black flies, but it is regarded as the most promising isolate for field use against mosquitoes (WHO 1985). Indeed, several authors have demonstrated the efficacy of strain 2362 against field populations of mosquitoes from the genera Culex, Anopheles, Psorophora, and some members of the genus Aedes. Ae. aegypti and Ae. albopictus are insensitive to B. sphaericus (Mulla et al. 1986, 1987, 1988a, b, Lacey et al. 1986, 1988, Nicolas et al. 1987, Berry et al. 1987, Arredondo-Jiménez et al. 1990, Karch et al. 1990). Abbott Laboratories has recently formulated a commercial product (Vectolex) of B. sphaericus 2362. Generally, B. sphaericus strains with high larvicidal activity have been isolated from dead insects (e.g., Weiser 1984, Lysenko et al. 1985, de Barjac et al. 1988, Gharib

This work is part of a Master Thesis of the first author, who was supported as a fellowship from CNPq.

${ }^{+}$Corresponding author.

Received 18 April 1996

Accepted 18 July 1996 et al. 1989). However, five isolates of B. sphaericus from soil samples in Israel have been reported to belong to phage group three and were found to be as toxic as strain 2362 to Culex sp. larvae (Brownbridge \& Margalit 1987). During a screening for entomopathogenic bacteria in soil samples carried out at CENARGEN/EMBRAPA in Brazil, several B. sphaericus isolates were obtained. One of these isolates (S2) showed high larvicidal activity in bioassays with $C x$. quinquefasciatus larvae (Schenkel et al. 1988). In this work, the larvicidal activity of the Brazilian isolate of $B$. sphaericus has been compared with strain 2362 in larvae of the mosquitoes $C x$. quinquefasciatus, $A n$. albimanus, An. quadrimaculatus, and Ae. aegypti.

\section{MATERIALS AND METHODS}

Bacterial isolates - B. sphaericus S2 was isolated from a soil sample in Brazil (Schenkel et al. 1988). The procedures outlined in the WHO protocol (1985) for selective isolation of insecticidal B. sphaericus from soil samples were employed. B. sphaericus 2362 was provided by Dr Howard Dulmage (USDA-Brownsville, Texas). Both strains were preserved at $4-8^{\circ} \mathrm{C}$ as lyophilized cultures grown in NYSM medium (Myers \& Yousten 1978). The Brazilian strain was characterized by Dr Allan Yousten as belonging to phage type three, which is the phage group of strain 2362 and other strains highly toxic to mosquito larvae. 
Growth in fermentor - A loopfull of lyophilized culture of each strain was seeded into $250 \mathrm{ml} \mathrm{Er-}$ lenmeyer flasks with $50 \mathrm{ml}$ of MBS medium (Kalfon et al. 1983) which contains per liter tryptone $10 \mathrm{~g}$, yeast extract $2 \mathrm{~g}, \mathrm{MgSO}_{4} 0.3 \mathrm{~g}$, $\mathrm{CaCl}_{2} 0.2 \mathrm{~g}, \mathrm{Fe}_{2}\left(\mathrm{SO}_{4}\right)_{3} 0.02 \mathrm{~g}, \mathrm{MnSO}_{4} 0.02 \mathrm{~g}$ and $\mathrm{ZnSO}_{4} 0.02$ g. Cultures were incubated in $\mathrm{G} 25$ New Brunswick rotary shakers at $30^{\circ} \mathrm{C}, 250 \mathrm{rpm}$. At late exponential phase, $100 \mathrm{ml}$ of culture was inoculated into a New Brunswick 14 liter fermentor with 10 liters of MBS broth $(1 \% \mathrm{v} / \mathrm{v})$. Batch fermentation was carried out at $30^{\circ} \mathrm{C}, 600 \mathrm{rpm}$ with air flow (1.0 liter/liter of broth/min) for $24 \mathrm{hr}$. Growth was monitored by reading of absorbance at $660 \mathrm{~nm}$. Samples taken every $2 \mathrm{hr}$ were filtered onto $0.45 \mu \mathrm{m}$ Millipore membranes, dried in an oven at $80^{\circ} \mathrm{C}$ for $24 \mathrm{hr}$ and used for dry weight determination. Although the $\mathrm{pH}$ of the broth was not controlled, the $\mathrm{pH}$ of the samples was recorded. Foam production during growth in the fermentor was reduced by the addition of silicone based antifoam (Sigma) previously diluted at $10 \% \mathrm{v} / \mathrm{v}$. The cultures were maintained in the fermentor for an additional $24 \mathrm{hr}$, without aeration and agitation. The final broth was centrifuged in a continuous flow system (Sorvall) at $10,000 \mathrm{~g}$ with a flow rate of approximately $30 \mathrm{ml} / \mathrm{min}$. The resulting creamy pellets were freeze dried. Spore counts were made by plating serial dilutions from $10 \mathrm{mg} / \mathrm{ml}$ suspensions of the dried cultures (primary powder). Before plating in solid MBS medium the samples were heated $15 \mathrm{~min}$ at $80^{\circ} \mathrm{C}$ and sonicated $1 \mathrm{~min}$ to unclump heat resistant spores. Three primary powders were produced for each strain (S2 and 2362).

Bioassay conditions - The protocol suggested in the WHO report (1985) was used with slight modifications to compare the toxicity of the primary powders against different mosquito hosts. The mosquito species Ae. aegypti, An. albimanus, An. quadrimaculatus, and $C x$. quinquefasciatus used in the bioassays were obtained from lab reared colonies at the USDA, Gainesville. One percent $(\mathrm{w} / \mathrm{v})$ stock suspensions of primary powder in deionized water were diluted to obtain seven concentrations with five replicates in each bioassay. Twenty second-instar larvae were placed per each $100 \mathrm{ml}$ disposable plastic cups filled with the test spore suspension, and five cups were left untreated as controls. A small amount of powdered dog chow was added to each cup. As an alternative, bioassays with Ae. aegypti were run in 24 well plates, with 10 first instar larvae per well, three replicates for each concentration tested, to minimize the consumption of primary powder. Bioassays of the first primary powder of each strain were replicated three times. The remaining batches were bioassayed only once for each mosquito species. Mortality was scored after $48 \mathrm{hr}$ of incubation at room temperature $\left(25^{\circ} \mathrm{C}\right)$ and the results were submitted to logprobit computer analysis (POLO-PC).

Toxin studies - Spore suspensions $(10 \mathrm{mg} / \mathrm{ml})$ were incubated in $50 \mathrm{mM} \mathrm{NaOH}, \mathrm{pH} 12$, for $2 \mathrm{hr}$ with the alkaline extraction procedure previously described (Davidson 1983). After centrifuging for $15 \mathrm{~min}$ at $10,000 \mathrm{~g}$ at $8^{\circ} \mathrm{C}$, the supernatant was filter sterilized and kept under refrigeration. Toxin was precipitated by the addition of sodium acetate buffer $\mathrm{pH} 4.0$, and the pellets obtained after centrifugation $(10,000 \mathrm{~g}, 20 \mathrm{~min})$ were suspended in $0.1 \mathrm{M}$ Tris. BCA reagent from Pierce Laboratories was used for protein determination in the alkali extracts. The toxin titer of each batch was estimated by ELISA (Engvall \& Perlman 1971) with antisera against the $42 \mathrm{kDa}$ toxin from $B$. sphaericus 2362 provided by Dr Elizabeth Davidson. Solubilized proteins were visualized in SDS-PAGE, electrotransferred onto nitrocellulose membrane by semi-dry system, and exposed to the antisera previously mentioned (dilution 1/1000).

\section{RESULTS}

The use of MBS medium to grow $B$. sphaericus S2 and 2362 in this study confirms previous observations about the efficacy of such a complex medium to produce larvicidal strains of $B$. sphaericus with high toxin yields (Kalfon et al. 1983). It was noticed, however, that a rather high level of foam was generated during exponential growth phase, and in late sporulation stage (lysis of sporangium).

The growth curves of the $B$. sphaericus strains 2362 and $\mathrm{S} 2$ in the 14 liter fermentor, showed similar profiles (Fig. 1). The data of dry weight on time collected from the fermentation runs was analyzed using paired t-test. The average dry weight observed for each strain (S2 1 vs S2 2, p=0.4049; 23621 vs 23622 , p=0.1681), as well as the averages between strains, do not differ significantly at the 0.05 level (Avg S2 vs Avg 2362, p=0.1033). Both strains reached stationary growth phase at 12 $14 \mathrm{hr}$, and completed sporulation at $24 \mathrm{hr}$, with many of the sporangia lysed, liberating free spores with attached parasporal bodies. In all of the fermentation runs change in $\mathrm{pH}$ showed a similar pattern, rising in the beginning of the log phase (around $4 \mathrm{hr}$ ), to reach about 8.5-8.6 at the end of growth (Fig. 1). Cell counts using a Petroff-Hauser counting chamber resulted in more than $10^{9}$ cells per $\mathrm{ml}$ at $24 \mathrm{hr}$ in all trials (data not shown). Spore counts of the primary powders presented in Table I indicate that strains S2 and 2362 sporulate at the same levels in MBS medium. The results of the ELISA of the alkali extracts of the cell preparations reflect the units of $\mathrm{OD}_{405} / \mathrm{mg}$ of primary 
powder (Table I). Table I also presents the results of the bioassays of individual fermentation that runs against the most susceptible species $C x$. quinquefasciatus and An. albimanus. A poor correlation between the $42 \mathrm{kDa}$ toxin titer measured by ELISA and the larvicidal potency of the primary powders has been observed. The variation among the LC data (50 and 90\%) of the primary powders is not statistically significant at the 0.05 level. Paired and independent t-test conducted with the bioassay data (LCs) showed that S2 and 2362 means are not different at the 0.05 level $(C x$. quinquefasciatus $\mathrm{p}=2.54$, and An. albimanus $\mathrm{p}=1.54$ ).

Sets of bioassay data obtained for individual primary powders were combined per strain. The larvicidal activity along with the mosquito species tested is summarized in Table II. In all the hosts the $\mathrm{LC}_{50}$ and $\mathrm{LC}_{90}$ of strain $\mathrm{S} 2$ is lower than those observed for strain 2362. However, the difference

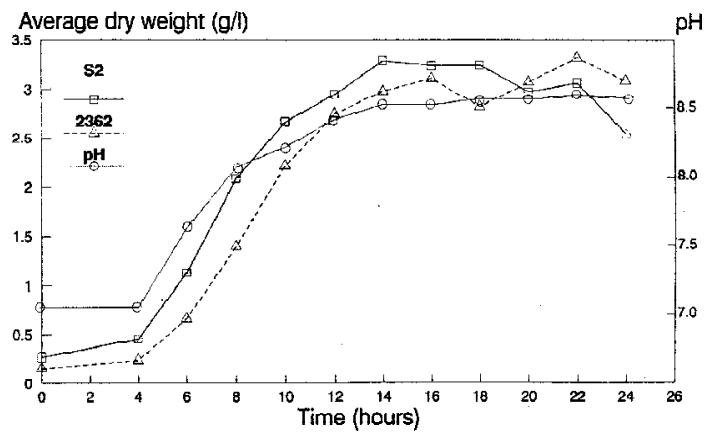

Fig. 1: growth pattern of Bacillus sphaericus strains S2 and 2362 in 141 fermentor. Average dry weight from three fermentation runs was used to plot the growth curves.

is not statistically significant. The $95 \%$ confidence limits around the $\mathrm{LC}_{50}$ and $\mathrm{LC}_{90}$ overlap. The slopes in all cases are similar, except in $C x$. quinquefasciatus. In this species the slope of the

TABLE I

Spore production and toxicity of the Bacillus sphaericus primary powders

\begin{tabular}{|c|c|c|c|c|}
\hline \multirow{2}{*}{ Primary powder } & \multirow{2}{*}{$\begin{array}{l}\text { Spores/mg }{ }^{a} \\
\text { (units/mg) }\end{array}$} & \multirow{2}{*}{ Toxin titer $^{b}$} & \multicolumn{2}{|c|}{$\mathrm{LC}_{50}{ }^{c}(95 \%$ confidence limits $)$} \\
\hline & & & $\begin{array}{l}\text { Culex } \\
\text { quinquefasciatus }\end{array}$ & $\begin{array}{l}\text { Anopheles } \\
\text { albimanus }\end{array}$ \\
\hline 23621 & $4.1 \times 10^{8} \pm 5.3$ & 11.3 & $0.42(0.36-0.47)$ & $7.5(5.50-10.0)$ \\
\hline 23622 & $2.2 \times 10^{9} \pm 1.3$ & 10.0 & $0.34(0.30-0.39)$ & $6.6(5.10-8.20)$ \\
\hline 23623 & $1.0 \times 10^{9} \pm 0.9$ & 13.7 & $0.17(0.15-0.19)$ & $3.9(3.40-4.40)$ \\
\hline S2 1 & $1.2 \times 10^{8} \pm 0.8$ & 19.0 & $0.29(0.25-0.35)$ & $3.0(2.00-4.10)$ \\
\hline S2 2 & $1.1 \times 10^{9} \pm 8.5$ & 7.7 & $0.13(0.11-0.15)$ & $14.9(11.7-19.4)$ \\
\hline S2 3 & $2.3 \times 10^{9} \pm 0.8$ & 10.7 & $0.27(0.24-0.29)$ & $2.9(2.40-3.50)$ \\
\hline
\end{tabular}

$a$ : mean of three replicates; $b$ : units of O.D. $405 / \mathrm{mg}$ of protein determined by Enzyme-Linked Immunosorbant Assay. Values were adjusted to toxin units/mg of primary powder; $c$ : values expressed in $\mathrm{ppb}(\mu \mathrm{g} / \mathrm{l})$.

TABLE II

Larvicidal activity of Bacillus sphaericus strains 2362 and S2 tested in four mosquito hosts. Lethal concentrations expressed in parts per billion result from bioassay data combined from three primary powders of each strain

\begin{tabular}{clclr}
\hline Host $^{a} / B$. sphaericus strain & $\mathrm{LC}_{50}$ & $\mathrm{LC}_{90}$ & Slope & $\mathrm{SD}$ \\
\hline $\begin{array}{c}\text { Culex quinquefasciatus } \\
2362\end{array}$ & $0.39(0.24-0.61)$ & $2.15(1.22-6.34)$ & 1.74 & \pm 0.05 \\
S2 & $0.25(0.19-0.31)$ & $1.00(0.75-1.52)$ & 2.12 & \pm 0.06 \\
Anopheles albimanus & & & & \\
2362 & $7.16(5.86-8.63)$ & $38.00(28.6-55.0)$ & 1.76 & \pm 0.04 \\
S2 & $5.95(4.66-7.49)$ & $31.20(22.5-49.2)$ & 1.78 & \pm 0.04 \\
Anopheles quadrimaculatus & & & & \\
2362 & $16.93(11.5-24.4)$ & $88.33(57.0-160.8)$ & 1.78 & \pm 0.05 \\
S2 & $12.28(8.67-16.9)$ & $62.69(43.1-101.6)$ & 1.81 & \pm 0.08 \\
Aedes aegypti & & & & \pm 0.16 \\
2362 & $307.00(200-450)$ & $1580.00(987-3,328)$ & 1.80 & \pm 0.18 \\
S2 & $140.00(062-243)$ & $830.00(453-3,055)$ & 1.65 & \\
\hline
\end{tabular}

$a$ : second instar larvae were used in the bioassays 
Brazilian strain is steeper (2.12) than that observed in strain 2362 (1.74). A comparison of the biological performance of the two strains is provided on the basis of the mortality plotted against log dose in Fig. 2. As it is demonstrated graphically the pattern of toxicity is very similar in all mosquito species tested.

The 51 and $42 \mathrm{kDa}$ toxic proteins reported elsewhere (Baumann et al. 1988, Broadwell et al. 1990), were visualized in SDS-PAGE of the alkali extracts from all primary powders. Elution of proteins from slab polyacrylamide gels onto nitrocellulose membranes, and further exposure to the 42 $\mathrm{kDa}$ antiserum, confirmed the presence of that peptide in crude extracts from both S2 or 2362 strains (Fig. 3).

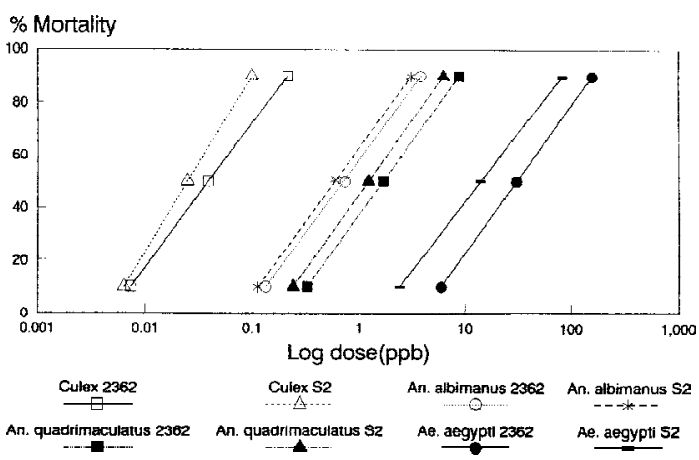

Fig. 2: larvicidal activity of Bacillus sphaericus.

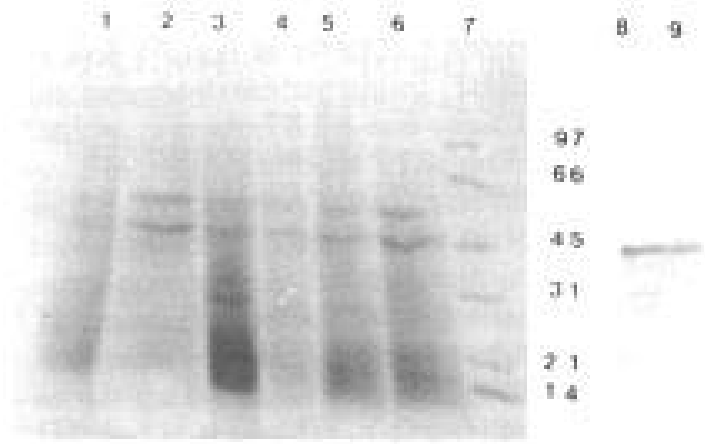

Fig. 3: gel electrophoresis (SDS-PAGE) of crude toxin extracts from Bacillus sphaericus strains S2 and 2362 in 5-20\% gradient (lanes 1-7). Lanes 1-3: S2 extracts; lane 7: molecular weight standards in kilodaltons; lanes 8-9: western immunoblots of extracts from strains S2 and 2362 developed with anti-42 $\mathrm{kDa}$ antisera.

\section{DISCUSSION}

As shown by the fermentor results, MBS medium supports a good yield for the $B$. sphaericus strains S2 and 2362 without significant differences in the growth profile. Larvicidal strains of $B$. sphaericus are regarded as a homogeneous group in physiological characters (de Barjac et al. 1980,
Krych et al. 1980, Priest et al. 1988). Based on these observations, and the fact that strains S2 and 2362 belong to the same phage type group, marked differences in the growth pattern are not very likely. The growth and spore production of strain 2362 observed in this work are in agreement with the results of Yousten and Wallis (1987) who employed a peptone based broth (NYSM). In four trials using a one liter New Brunswick fermentor, with the same aeration and without $\mathrm{pH}$ control, Yousten and Wallis obtained spore counts of 6.0$8.6 \times 10^{8}$ spores $/ \mathrm{ml}$ of final broth of B. sphaericus 2362. This study reports spore counts between 1.2 $\times 10^{8}$ to $2.3 \times 10^{9} / \mathrm{mg}$ (dry weight) in the primary powder of B. sphaericus $\mathrm{S} 2$, and $4.1 \times 10^{8}-2.2 \times$ $10^{9}$ in B. sphaericus 2362 (Table I). During fermentation a significant amount of foam was produced which resulted in the incorporation of varying amounts of anti-foam which remains as a component of the primary powders. The variable amount of anti-foam used during the fermentation runs may explain in part the variation in the calculated number of viable spores per mg of primary powders. Other factors that may account for variation in the spore number of individual preparations are the recovery process (continuous flow centrifugation, lyophilization), the standardization of the inoculum (initial cell count), and the standardization of the growth conditions (aeration, agitation). The larvicidal potency in the cultures produced by Yousten and Wallis (1987) was measured in comparison with the International Standard RB-80 (Pasteur Institute, France), and expressed in toxic units per milliliter of broth. The way the larvicidal toxicity is presented in this paper does not allow comparison of results. However, it is relevant for this work that Yousten and Wallis (1987) report a potency range in $C x$. quinquefasciatus from $7728-$ 14144 toxin units/mg dry weight for the four trials mentioned above, which represents a variation of up to $100 \%$ among batches of B. sphaericus 2362 in NYSM broth. As shown in Table I, a similar variation in the potency in terms of $\mathrm{LC}_{50}$ and $\mathrm{LC}_{90}$ of the primary powders of $B$. sphaericus $\mathrm{S} 2$ and 2362 was observed.

The high levels of toxicity of the strains S2 and 2362 in Cx. quinquefasciatus were followed by lower levels in An. albimanus and An. quadrimaculatus (20-40 fold higher $\mathrm{LC}_{90}$ 's), with the lowest larvicidal activity observed in Ae. aegypti (Table II). Several authors have observed this larvicidal profile for B. sphaericus 2362 and other strains (Lacey \& Singer 1982, Mulla et al. 1986, Ali \& Nayar 1986, Wraight et al. 1987). As reviewed by Lacey and Undeen (1986), $B$. sphaericus spore/crystal preparations kill $A e$. aegypti larvae at dosages 100-1000 fold greater 
than that required for $C x$. quinquefasciatus. An explanation for this pattern has been proposed by Davidson (1989), based upon the affinity that FITC-labeled toxin binds to midgut of larvae of these mosquito species. It was shown that the toxin does not bind to the midgut of Ae. aegypti larvae, and binds with low affinity to Anopheles sp. larvae. De Barjac et al. (1988) report $\mathrm{LC}_{50}$ 's at dilutions of 7.2-8.5 $\times 10^{-4}$ of final whole cultures of $B$. sphaericus 1593 and 2362 respectively, in fourth instar larvae of Ae. aegypti. In second instar larvae there are reports of $\mathrm{LC}_{50}=189 \mathrm{ppm}$ with strain SSII-1 (Wraight et al. 1987), LC $_{50}=57.2 \mathrm{ppm}$ with strain 1593 (Mulla et al. 1983), and $\mathrm{LC}_{50}>50 \mathrm{ppm}$ (third instar larvae) with strains 1593 and 2362 (Ali $\&$ Nayar 1986). The results found in this work fall in a range well below previous reports. Indeed, even for $C x$. quinquefasciatus, a similar high level of larvicidal activity has been reported by Myers and Yousten (1981), who found an $\mathrm{LC}_{50}=0.37 \mathrm{ppb}$ with pure spores (washed free of culture residues) of strain 1593 in second instar larvae of $C x$. quinquefasciatus. Yousten (1984) reports $\mathrm{LC}_{50}$ 's of 0.04-0.07 ppb with pure spores of strain 2362 in second instar $C x$. quinquefasciatus. Mulla et al. (1986) tested a primary powder of B. sphaericus 2362 produced by Abbott Laboratories (ABG$6184)$ in lab-reared fourth instar $C x$. quinquefasciatus larvae, and found an $\mathrm{LC}_{90}=8.0$ $\mathrm{ppb}$. The lowest values of $\mathrm{LC}_{50}$ obtained with anopheline mosquitoes are reported by Lacey and Singer (1982). These authors observed $\mathrm{LC}_{50}$ values of 18.7-52.7 ppb in second instar An. albimanus and $A n$. quadrimaculatus, respectively, with $B$. sphaericus strain 2013-4 from Romania. The overall comparison indicates that the preparations of B. sphaericus $\mathrm{S} 2$ and 2362 obtained in this work are among the most potent, in terms of larvicidal activity for the mosquito species tested.

The use of ELISA with anti-42 kDa antisera failed to provide a good correlation of larvicidal potency with titer of $42 \mathrm{kDa}$ toxin in individual preparations. One reason for this can be the absence of the anti-51 kDa toxin IgG in the antisera used for the ELISA titration. The binary action of the 42 and $51 \mathrm{kDa}$ peptides in the process of toxicity of B. sphaericus has been established (Broadwell et al. 1990, Davidson et al. 1990). The role of a third $100 \mathrm{KDa}$ toxin previously characterized (Davidson 1983) which may be influencing the results obtained in this research has been established elsewhere (Thanabalu et al. 1991).

As revealed by the polyacrylamide gel of the toxin extracts (Fig. 3), B. sphaericus $\mathrm{S} 2$ shows a protein profile typical of the highly larvicidal strains. Previous research has demonstrated the similar toxin profile among the B. sphaericus toxin producer strains (Baumann et al. 1985, De Barjac et al. 1988). Schenkel et al. (1992), demonstrated that S2 and three other B. sphaericus isolates from Brazilian soils, belong to serotype $\mathrm{H} 5$ and produce the toxins found in 2362 strain. It was also demonstrated that these strains were different from 2362 and from each other, based on gas chromatography analysis of fatty acids.

Data generated in laboratory bioassays suggest a trend in strain S2 towards a toxicity higher than that observed in strain 2362 against the mosquito species tested. Additional research should provide valuable information with regard to the field performance of the new isolate.

\section{ACKNOWLEDGEMENTS}

To Drs Drion Boucias and Jeffrey Lord, who provided scientific advice and lab support to the author.

\section{REFERENCES}

Ali A, Nayar JK 1986. Efficacy of Bacillus sphaericus Neide against larval mosquitoes (Diptera: Culicidae) and midges (Diptera: Chironomidae) in the laboratory. Flor Entomol 69: 685-690.

Arredondo-Jiménez JI, López T, Rodriguez MH, Bown DN 1990. Small scale field trials of Bacillus sphaericus (strain 2362) against Anopheline and Culicine mosquito larvae in Southern Mexico. $J$ Am Mosq Control Assoc 6: 300-305.

Baumann L, Broadwell AH, Baumann P 1988. Sequence analysis of the mosquitocidal toxin genes encoding 51.4- and 41.9-kilodalton proteins from Bacillus sphaericus 2362 and 2297. J Bacteriol 170: 20452050.

Baumann P, Unterman BM, Baumann L, Broadwell A H, Abbene SJ, Bowditch RD 1985. Purification of the larvicidal toxin of Bacillus sphaericus and evidence for high-molecular-weight precursors. $J$ Bacteriol 163: 738-747.

Berry C, Hindley J 1987. Bacillus sphaericus strain 2362: identification and nucleotide sequence of the 41.9 kDa toxin gene. Nucleic Acids Res 15: 758-764.

Broadwell AH, Baumann L, Baumann P 1990. Larvicidal properties of the 42 and 51 Kilodalton Bacillus sphaericus proteins expressed in different bacterial hosts: evidence for a binary toxin. $J$ Bacteriol 172: 2217-2223.

Brownbridge M, Margalit J 1987. Mosquito active strains of Bacillus sphaericus isolated from soil and mud samples collected in Israel. J Invertebr Pathol 50: 106-112.

Davidson EW 1983. Alkaline extraction of toxin from spores of the mosquito pathogen, Bacillus sphaericus strain 1593. Can J Microbiol 29: 271-275.

Davidson EW 1989. Variation on binding of Bacillus sphaericus toxin and Wheat Germ Agglutinin to larval midgut cells of six species of mosquitoes. J Inv Pathol 53: 251-259.

Davidson EW, Oei C, Meyer M, Bieber AL, Hindley J, Berry C 1990. Interaction of the Bacillus sphaericus mosquito larvicidal proteins. Can J Microbiol 36: 870-878. 
de Barjac H, Thiery I, Cosmao-Dumanoir V, Frachon E, Laurent P, Charles J-F, Hamon S, Ofori J 1988. Another Bacillus sphaericus serotype harboring strains very toxic to mosquito larvae: Serotype H6. Ann Inst Pasteur/Microbiol 139: 363-377.

de Barjac H, Veron M, Cosmao-Dumanoir V 1980. Caracterisation biochimique et serologique de souches de Bacillus sphaericus pathogenes ou non pour les moustiques. Ann Microbiol 131B: 191-201.

Engvall E, Perlman P 1971. Enzyme-linked immunosorbent assay (ELISA). Quantitative assay of immunoglobulin G. Immunochem 8: 871-874.

Gharib AH, Wyman JA, Shihata ZA 1989. Laboratory evaluation of three pathogenic strains of Bacillus sphaericus isolated in Egypt. J Inv Pathol 54: 57-62.

Kalfon A, Larget-Thiery I, Charles J-F, de Barjac H 1983. Growth, sporulation and larvicidal activity of Bacillus sphaericus. Eur J Appl Microbiol Biotechnol 18: 168-173.

Karch S, Monteny N, Jullien JL, Sinegre G, Coz J 1990. Control of Culex pipiens by Bacillus sphaericus and role of nontarget arthropods in its recycling. J Am Mosq Control Assoc 6: 47-54.

Krych VK, Johnson JL, Yousten AA 1980. Deoxyribonucleic acid homologies among strains of Bacillus sphaericus. Int J Syst Bacteriol 30: 476-484.

Lacey LA, Heitzman CM, Meisch M, Billodeaux J 1986. Beecomist applied Bacillus sphaericus for the control of riceland mosquitoes. J Am Mosq Control Assoc 2: 548-551.

Lacey LA, Ross DH, Lacey CM, Inman A, Dulmage HT 1988. Experimental formulations of Bacillus sphaericus for the control of anopheline and culicine larvae. J Ind Microbiol 3: 39-47.

Lacey LA, Singer S 1982. Larvicidal activity of new isolates of Bacillus sphaericus and Bacillus thuringiensis (H-14) against Anopheline and Culicine mosquitoes. Mosq News 42: 537-543.

Lacey LA, Undeen A 1986. Microbial control of mosquitoes and black flies. Annu Rev Entomol 31: 265296.

Lysenko O, Davidson EW, Lacey LA, Yousten AA 1985. Five new mosquito larvicidal strains of $B a$ cillus sphaericus from non-mosquito origins. $J$ Am Mosq Control Assoc 1: 369-371.

Mulla MS, Darwazeh HA, Aly C 1986. Laboratory and field studies on new formulations of two microbial control agents against mosquitoes. Bull Soc Vector Ecol 11: 255-263.

Mulla MS, Darwazeh HA, Yousten AA 1987. Bacillus sphaericus 2362 formulations for initial and persistent control of stagnant water mosquitoes. Proc Pap Calif MosqVector Control Assoc 55: 50-57.

Mulla MS, Axelrod H, Darwazeh HA, Matanmi BA 1988a. Efficacy and longevity of Bacillus sphaericus 2362 formulations for control of mosquito larvae in dairy wastewater lagoons. J Am Mosq Assoc 4: 448452.
Mulla MS, Darwazeh HA, Tietze NS 1988b. Efficacy of Bacillus sphaericus formulations against floodwater mosquitoes. J Am Mosq Contol Assoc 4: 172174.

Mulla MS, Darwazeh HA, Aly C 1986. Laboratory and field studies on new formulations of two microbial control agents against mosquitoes. Bull Soc Vector Ecol 11: 255-263.

Mulla MS, Darwazeh HA, Ede L, Chaney JD, Mian LS, Aly C, Wargo MJ 1983. Microbial control agents as mosquito larvicides. Mosq-Control-Res-Annu-Rep., University of California, p. 54-58.

Myers PS, Yousten AA, Davidson EW 1978. Bacillus sphaericus mosquito larval toxin. Proc. Intl. Congress Microbiol., Munich.

Myers PS, Yousten AA 1981. Toxic activity of Bacillus sphaericus for mosquito larvae. Dev. Ind. Microbiol p. 41-52. Soc. Ind. Microbiol., Proc. 37th Gen. Mtg.

Nicolas L, Dossou-Yovo J, Hougard J 1987. Persistence and recycling of Bacillus sphaericus 2362 spores in Culex quinquefasciatus breeding sites in West Africa. Appl Microbiol Biotechnol 25: 341-345.

Priest FG, Goodfellow M, Todd C 1988. Numerical classification of the genus Bacillus. J Gen Microbiol 134: 1847-1882.

Schenkel RGM, Vilarinhos P de TR, Honda CS 1988. Isolamento de uma cepa de bacilo entomopatogênico na região do Distrito Federal. II Encontro Nacional de Microbiologia Ambiental. Águas de Lindóia - SP, Abstracts.

Schenkel RGM, Nicolas L, Frachon E, Hamon S 1992. Characterization and toxicity to mosquito larvae of four Bacillus sphaericus strains isolated from Brazilian soils. J Inv Pathol 60: 10-14.

Thanabalu T, Hindley J, Jackson-yap J, Berry C 1991. Cloning, sequencing, and expression of a gene encoding a 100-kilodalton mosquitocidal toxin from Bacillus sphaericus SSII-1. J Bacteriol 173: 27762785.

Yousten AA, Wallis DA 1987. Batch and continuous culture production of the mosquito larval toxin of Bacillus sphaericus 2362. J Ind Microbiol 2: 277-283.

Yousten AA 1984. Bacillus sphaericus: Microbiological factors related to its potential as a mosquito larvicide, p. 315-344. In A Mizahi \& AL Van Wezel (eds) Advances in Biotechnology Processes, vol. 3, AR Liss, NY.

Weiser J 1984. A mosquito-virulent Bacillus sphaericus in adult Simulium damnosum from Northern Nigeria. Zbl Mikrobiol 139: 57-60.

WHO 1985. Informal Consultation on the Development of Bacillus sphaericus as a Microbial Larvicide. $\mathrm{TDR} / \mathrm{BCV} / 85.3$.

Wraight SP, Molloy DP, Singer S 1987. Studies on the Culicine mosquito host range of Bacillus spahericus and Bacillus thuringiensis var. israelensis with notes on the effects of temperature and instar on bacterial efficacy. J Inv Pathol 49: 291-302. 